\title{
KARYA SENI INDONESIA SEBAGAI OBJEK \\ PERLINDUNGAN HAK CIPTA: \\ JANGKAUAN DAN PERMASALAHAN
}

Djoko Saryono

\section{Fakultas Sastra Universitas Negeri Malang}

\section{Abstract}

As an intellectual creation, arts have long become the objects of copyright protection. International copyright regulations have been legislated and many have been ratified. Indonesia has also established such regulations as well as ratified the international patent laws to protect art works. The regulations are relatively adequate, however, the implementation and the control are still very bad.

Key words: arts works, protection, and copyright

\section{A. Pendahuluan}

Pada dasarnya, karya seni sudah diberi perlindungan hukum secara formal atau yuridis. Buktinya, sudah ada berbagai peraturan perundang-undangan nasional dan internasional yang mengatur perlindungan hak cipta atas karya seni.

Dalam berbagai peraturan perundang-undangan nasional dan internasional mengenai Hak Cipta Kekayaan Intelektual (selanjutnya disingkat HaKI) khususnya Hak Cipta, karya seni sudah lama disebut, dijadikan atau dicantumkan sebagai salah satu ciptaan kreatif yang memperoleh perlindungan hak cipta. Sebagai contoh, Konvensi Bern yang telah dicetuskan pada tahun 1886 (baca: Abad XIX!) secara khusus berisikan pengaturan perlindungan hak cipta karya seni dan sastra (sic!). Di samping Konvensi Bern, ada juga berbagai peraturan perundang-undangan internasional yang mengatur perlindungan karya seni yang sudah diratifikasi oleh pemerintah Indonesia. Demikian juga Undang-undang Hak Cipta 1997 yang kini dimiliki dan berlaku di Indonesia juga mencantumkan karya seni (di samping banyak lainnya) sebagai salah satu objek perlindungan hak cipta (bagian V, pasal 11). Hal ini jelas membuktikan betapa kehendak dan perhatian hukum yang serius sudah diberikan kepada karya seni dalam bentuk memberikan perlindungan hak cipta.

Sehubungan dengan itu, timbul pertanyaan: Mengapa karya seni mendapat perlindungan hak cipta baik nasional maupun internasional? Tulisan ini mencoba memaparkan konteks dan argumen atau rasionel di balik pemberian perlindungan hak cipta atas karya seni menurut perspektif kebudayaan atau seni. Selain itu, dipaparkan juga jangkauan perlindungan hak cipta atas karya seni. Secara problematis di sini dipaparkan karya seni apa saja yang sudah dijangkau oleh perlindungan hak cipta. Tulisan ini selanjutnya memaparkan permasalahan 
lebih melihat hubungan-hubungan sebab akibat yang tak terlihat sebelumnya. Keyakinan akan pentingnya fantasi itu pulalah yang mendorong Albert Einstein menyarankan seorang ibu, yang kala itu bertanya apa yang harus ia lakukan untuk mengasah talenta anaknya, untuk tak lelah membacakan mitos-mitos besar masa lampau dan senantiasa mempertajam imajinasinya. "Read him the great myths of the past and stretch his imagination", katanya kepada ibu tersebut.

Menyadari pentingnya fantasi Chukovsky (dalam Jacobs, 2000) menyatakan bahwa fantasi merupakan "the most valuable attribute of the human mind, and should be diligently nurtured from the earliest age". Fantasi sangat bernilai dalam proses pembentukan kalbu manusia dan oleh karenanya harus dengan tekun diperkenalkan pada anak-anak semenjak usia dini.

Memang ada beberapa kekhawatiran terhadap fantasi yang berlebihan, dan itu cukup dimengerti. Misalnya beberapa orang tua atau guru mengkhawatirkan tumbuhnya fantasi psikologis, yakni penyakit psikologis di mana penderita tidak mampu membedakan realita dan khayalan. Namun beberapa pakar seperti Bruno Bettleheim (dalam Jacobs, 2000) menegaskan bahwa penyakit fantasi psikologis tidak disebabkan oleh cerita-cerita fantasi, melainkan oleh tekanan psiko sosial yang mereka alarm. Justeru sebaliknya, anak-anak yang memiliki pengalaman membaca atau menonton cerita-cerita fantasi pada umumnya memiliki resiko yang lebih rendah untuk mengidap penyakit fantasi psikologis, karena mereka mampu mengolah rasa frustrasi akiba tekanan psiko sosial yang mereka alami. Cerita fantasi tidak hanya aman bag anak-anak, tetapi juga penting bagi mereka. Anak-anak yang dilarang mekonsumsi cerita-cerita fantasi pada umumnya cenderung mencari pelarian psikologis yang lain. Dan kemungkinan pelarian tersebut dapat melalui astrologi, black magic atau justeru narkoba.

\section{Membangun Imajinasi dan Fantasi Melalui Buku Cerita Bergambar}

(BCB)

Setelah menyimak beberapa butir yang mengukuhkan betapa pentingnya imajinasi dalam kehidupan dan terutama dalam pendidikan, pertanyaan yang sering muncul adalah apakah daya imajinasi dapat diajarkan?; ataukah itu merupakan bakat alamiah yang dibawa sejak lahir? Beberapa pakar secara optimis berpendapat bahwa imajinasi dapat dirangsang untuk tumbuh. Dan kegiatan merangsang tumbuhnya imajinasi ini dapat dan bahkan dianjurkan dilakukan semenjak dini. Untuk merangsang tumbuhnya daya imajinasi anakanak, sastra anak memiliki peran yang tidak kecil. Buku Cerita Bergambar (BCB) dan khususnya cerita fantasi dapat merupakan lahan stimulan imajinasi yang sangat baik.

Tentu saja tidak sembarang BCB atau cerita fantasi dapat merangsang daya imajinasi. Ada beberapa karakteristik dari BCB dan cerita fantasi yang mampu membangkitkan imajinasi pembacanya. Gambar-gambar dalam BCB
Hal lain yang bisa dilakukan untuk menjaga logika dan kepercayaan adalah melalui penambatan kepada realitas. Di tengah-tengah elemen yang fantastis, dalam latar atau setting suatu cerita fantasi perlu dihadirkan penggambaran yang rinci dari sudut sudut atau benda-benda di ruangan tersebut. Ketika menggambarkan King Kong menguasai kota New York, misalnya, Anthony Browne merasa perlu menggambarkan kota New York dengan tata letak dan ketinggian gedung seperti aslinya. Gedung Empire State Building digambarkan dengan lekuk-lekuk dan bentuk yang persis seperti aslinya. Hal yang sama terjadi ketika penulis menggambarkan puncak menara di mana monster itu berdiri. Dari puncak menara itu tampak panorama kota New York yang terlihat dari sudut pandang tersebut, lengkap dengan puncak Cathedral dan jembatan di seberangnya. Penghadiran detil yang sesuai aslinya ini merupakan upaya untuk anchoring fantasy in reality, upaya untuk menambat fantasi dalam bingkai realitas. Menurut Stewig (1980), semakin fantastis sebuah teks fantasi, semakin tinggi kebutuhan untuk menambatkannya dengan dunia riyata.

Dari paparan di atas dapat disimpulkan bahwa imajinasi dan fantasi bukanlah barang 'haram' yang perlu dihindari dalam pendidikan. Imajinasi dan fantasi justeru merupakan bagian penting dalam pendidikan dan perkembangan ilmu pengetahuan, dan oleh karenanya perlu menyertai segenap aktivitas pembelajaran. Agar dapat berkembang dengan baik, imajinasi dan fantasi anak disarankan untuk selalu dirangsang sejak mereka berusia dini.

Berbagai karya seni, dan pada khususnya sastra memiliki potensi untuk merangsang imajinasi dan fantasi anak. Buku Cerita Bergambar yang baik, yang memenuhi beberapa syarat tertentu, seperti telah dipaparkan di atas, memiliki potensi untuk membantu merangsang imajinasi anak pada usia dini.

\section{DAFTAR PUSTAKA}

Abbot, Edward. 2004. Poepav. http://www.poepauv.com/articles/overworked. html. downloaded 23 February 2007-02-28

Browne, Anthony. 1994. King Kong. London: Julia MacRae Books

Handayani, T.S. 2005. Fantasy in Joanne Kathleen Rowling's Harry Potter and the Sorcerer's Stone. Yogyakarta: English Language and Literature Department, Yogyakarta State University

Jacobs, James and Tunnel, Michael. 2000. Children's Literature Briefly. New Jersey. Prentice Hall

Mitchell, Diana. 2003. Children's Literature: An Invitation to the World. New York: AB Publishing

Scieszka, Jon dan Smith, Lane. 1995. Math Curse. New York: Penguin

Shannon, David. 1998. No, David!. New York: Scholastic Inc.

Stewig, John.1980. Children and Literature. Chicago. Rand McNally Publishing Company 
